\title{
The Use of Politeness in Tourism Communication: Research on Japanese Language Interaction During Tour Trip
}

\author{
Zanjabila Binti Nudin*, Roswati Abdul Rashid and Ahmad Shamil Bin Kamaruzaman \\ Universiti Malaysia Terengganu (UMT), Terengganu \\ *Corresponding author.Email: p4213@pps.umt.edu.my
}

\begin{abstract}
Politeness in Japanese society is highly perceived in social interaction especially politeness in business interaction where in Japanese culture customers must be served with high degree of politeness as they are regarded as the (customer as the god) concept. In this context, inquiry on the (im)politeness interaction between Japanese speaking Malaysian tour guide and Japanese tourists during a tour trip session is crucial in examining the Japanese tourists perception on the use of (im)politeness to decide at what extend the host is polite or impolite during the interaction and are there exceptions for non-native speaker such as given the flexibility to not adhere to the Japanese norms? Thus, this study aims to determine Japanese tourists' perspective from the use of politeness by Japanese speaking Malaysian tourist guide. Questionnaire is used as the research techniques in collecting data. This study involves 200 Japanese tourists visiting Malaysia selected using purposive sampling. The expected result of this study is assisting tour guide in using the expected politeness aspect in order to avoid Face Threatening Act (FTA) which will affect the satisfaction of the tour trip and most likely politeness aspect will be neglected as the most important element is the tour guide successfully conveyed the particular information during the tour guiding session.
\end{abstract}

Keywords: Perception, Japanese Tourists, Tour Guide, Japanese Tourists, (Im)politeness, Tour Trip

\section{INTRODUCTION}

From the year 2013 until 2018, Japan managed to take a spot in the top 10 generating markets in Malaysia. In line with this growth, it proves that Japanese tourists prefer to travel in groups or package tour, especially among female travellers. This statement is backed up by the Japanese Marketing company (JTM) that package tours are in demand among women [1]. Furthermore, Yamamoto and Gill (1999) [1] identify that majority of Japanese package tourists hold low proficiency in English in terms of reading, writing and speaking. The number of tourists guide who is an expert in the foreign language (Japanese language) is 647. Yamamoto and Gill (1999) [1] also assert Japanese tourists feel they lack confidence communicating in English. Consequently, tour guide is an option to be their intermediary when travelling to foreign countries.

The impoliteness in Japanese linguistic politeness used by tour guide is identified as an irrelevant factor in affecting and influencing the quality of the guided tour sessions as tour guide only require to pass the Japanese Language Proficiency Test (JLPT) at average level and the utmost critical aspect is the intended message or information is successfully delivered [2]. Nevertheless, incompetence in mastering clients' language will somehow hit the level dissatisfaction of the clients.

Research found that if unsuitable honorific expressions are used with customers and clients, the speaker's action seems to be impolite [3]. Furthermore, it is found that several Japanese speaking tourist guides only use teeneego -level (politeness form) [4]. Besides that, they tend to use the explicit form and vocabularies, which are inappropriate when interacting with Japanese tourists [4]. This situation contradicts with Japanese culture where it is intolerable that less formal language is used when speaking to superior [5]. Thus, this study is carried out to determine Japanese tourists' perception of the use of politeness by Japanese speaking Malaysian tour guide. 
Definition of politeness varies between western and eastern scholars, they defined politeness according to their standpoint. Politeness is defines differently based on how people views it. This can be seen in the study conducted by Yan Yibo (2015) [6] which compares Chinese tend to value collectivism emphasize on group orientation which building a harmonious relationship with others within the group while English people tend to prioritize individualism which they tend to care about one's self-care and cater their need first.

Politeness relates contributing to building rapport environment and refrain from occurrence of social conflict. Polite language is the yardstick of the society's conformity to the language rule of a community. More particularly, linguistic politeness involves communication strategies which are recognized and evaluated by community as having been used to maintain relations and avoid causing inconvenience. Every society or community has their own language rules [7].

Politeness is a branch in the pragmatic field. The early pioneer of politeness was introduced by Goffman [8] in his work On Face Work. He focused on behaviour associated with the concept of face when interacting in a particular context. Face is interpreted as an image a person want to claim for him/herself. Lakoff (1973) [9] introduces politeness principle with three rules, 1) Do not Impose, 2) Give Options and 3) Make the Listener feel comfortable. In that year as well, Grice (1975) [10] through his writing in Logic and Conversation propose Grice's Cooperative Principle to understand politeness. The most popular politeness theory introduces by Brown and Levinson use Grice's face theory as their basis of the study.

Face is generally known as a person's dignity. However, face defined by Brown and Levinson is an image a person in every community value and maintained. They discussed face is categorised into two category as positive and negative face. Positive face is described as the desire of a person to be accepted and liked by others. Positive politeness is the efforts to preserve the positive face of others. Negative face refers to the person's autonomy and rights are not invaded. The orientation of negative politeness accounts for the avoid of imposition of negative face of others. Face is presumed as a universal idea in any society. Generally, speakers and hearers ideally will try to take care of each other faces.

Politeness is realised in speech act [11]. Speech act such as complaint, disagreement and request will threaten the face. These acts are called Face Threatening act (FTA). FTA can threaten positive, negative and both at once. Three variables are considered in determine the weight of FTA which are social distance (D) between speaker and hearer, power and range of imposition (R). There are five strategies to be chosen by an individual to avoid or weaken the risk of FTA such as implement the FTA on record or off record. Then, if the bald on record strategies is implement, the individual is given the chance to utilise the bald on record with or without improving the situation. In the context of improving the situation, the speaker can choose to use positive politeness and negative politeness.
The last strategy is the speaker is given the choice to not implement FTA in his/her interaction.

However, some of the scholars encounter some difficulties to imply Brown and Levinson's theory into other culture especially eastern cultures as their theory is universal. (Matsumoto, 1988, 1989 and Ide, 1989) [12]-[13] find out it is not suitable to implement Brown and Levinson's theory into Japanese politeness.

Japanese politeness can be seen through its linguistic form of their language and it is conceptualized in their society [14]. Brown and Levinson politeness theory had been challenged by Japanese scholars. Some claimed the theory is non-applicable to eastern cultures as the use of language differs [5]. Consequently, Matsumoto's Japanese Politeness theory (1988) [12] was proposed as Brown \& Levinson theory contradicts with Japanese politeness. He then explained the western theory is not suitable for Japanese society as they are more concerned with individualistic.

Ide (2001) [15] revealed that there are two topologies of Japanese politeness which are discernment and volition. Discernment originates from "wakimae" in Japanese, discernment is based on the choice of the speaker's perspectives on the social rank, relationship between the interlocutor, and the conformity to the social norms. Discernment is expressed through formal linguistic politeness. Meanwhile, volition is expressed through verbal strategies and the speaker must implement strategies to avoid and lessen the face threatening act. Thus, he/she has the desire to be polite in interaction. Matsumoto (1988) [12] and Ide (2001) [15] insist that Brown and Levinson theory is based on volition as it utilized verbal strategies to keep being polite in an interaction.

Discernment is the basis of the Japanese politeness. Japanese society is described as vertical society since they are structured from the basis of frames. They are grouped in hierarchy based on their sense of place toward addresser [16].

Japanese business philosophy asserts the service provider in Japanese society is expected to be using formal language when delivering service such as implement honorific language. Enamoto (1998) [17] was the one to start off study on foreign tourist guide who can speaks Japanese language, and he was the one who started the evolution of the study. He examines the use of Japanese linguistic politeness by Australian tourist guide Japanese speaker from the perspective of Japanese tourists. Finding shows some forms of impoliteness in utterances such as $n$ desu form, ne-form and referent addressing form. These tourists guide was not exposed to the real situation which causing them to choose inappropriate honorific language according to the situation. He also assumes the occurrence of this phenomenon is originate from the lack of training and limited use of linguistic features in Japanese language. Roslina Mamat (2010) [18] investigated the pattern use of Japanese linguistic politeness in a tour guiding session in Malaysia. Interaction between four tourism personnel and Japanese tourists was recorded. It is found that most of the utterance by the tourism personnel failed to use the least 
polite form which is teenegoo. This shows that with only a basic command of the Japanese language, the tourism personnel faced difficulties in conveying and delivering the essence of the information.

Roslina Mamat, Hazlina Abdul Halim, Normaliza Abd Rahim (2012) [19] conducted a study on Japanese language characteristic, insertion in conversation between Malaysian Japanese speaker tourist guide and Japanese tourists. Insertion is impoliteness since it can disturb the interaction as speaker and hearer play a crucial role in an interaction, respectively. Insertion happen because of tourist guide failure to get a good grasp of Aizuchi such as "anou, ee, hai" and insertation happens when the hearer states his agreement or objections when aizuchi is realized. Finding shows there are two types of insertion which are intended to assist and disrupt the conversation. The purpose of using these strategies are used to reduce face threatening act (FTA) and in ensuring harmonious relationship between tourist guide and Japanese tourists. The author also revealed the tour guide in Bali used only in teeneego form which coincides with study conducted by Roswati Abdul Rashid, Isma Rosila Ismail, Radhiah Ismail, Roslina Mamat (2017) [4] also claim that Malaysian Japanese tour guide use teeneego form which is the least polite form in Japanese linguistic politeness.

Garay (2019) [20] carried out a qualitative study to find out the strategies of linguistic politeness implement by tourism staff towards local tourists when they visited Mt. Hamiguitan UNESCO World Heritage Site. However, the finding showed the tourism staffs inconsistently enforce politeness either verbal or non-verbal in their interaction. Unconsciously, this situation will be considered rude and the tourists will be in an awkward, discomfort state and will leave a bad impression on the place they visited.

Anak Agung Ayu Dian Andriyani, Djatmika, Sumarlam and Ely Triasih Rahayu (2019) [21] looked into linguistic politeness strategies used by tourism actors in Bali. The finding showed majority of the strategies used to cater the tourists is both of positive and negative politeness strategies by using teeneego form as the honorific form. Superficial depth understanding by tourism actors in Bali influence the tourism actors' proficiency language and fail to use the right linguistic politeness according to the asocial distance between host and client.

\section{METHODOLOGY}

This study uses quantitative method to investigate the Japanese tourists' perceptions on the use of "Japanese Politeness by Malaysian Japanese Language tourist guide while conducting tour trip. It focused on:

(1) to identify to the usage level of Japanese politeness among Japanese speaker tourist guide.

(2) to determine if there is a significant effect of tour session smoothness on tourists' satisfaction.

(3) to determine if there is a significant effect of the Japanese speaker tourist Japanese

politeness's practice on tourists' satisfaction.

\subsection{Respondent}

The respondents of this study consisted of 227 of Japanese tourists who participated in tour guiding session conducted by a Japanese speaker Malaysian tour guide. Because of Corona virus spread in Malaysia, the data collection process was disrupted and did not reach the target of 300 respondents as the minimum population outlined. 227 respondents of these tourists consisted of tourists who participate in seven guiding session. Tourist destination visited such as Kuala Lumpur, Melaka and Pulau Pinang.

\subsection{Instrument}

The Instrument used in this study is questionnaire. The questionnaire was used in order to measure the satisfaction of Japanese tourists on the quality of the guiding session. Questionnaire was formulated into Likert Scale form consisted of 40 items in Japanese language. The questionnaire was validated by Cronbach alpha analysis to ensure the items were suitable to be keep in the questionnaire, the questionnaire also needed to be administered to experts of linguists in the research experience on Japanese politeness to examine the items.

The questionnaire applied through combining dimensions of model Yu et. al. (2002) [22], Leclerc and Martin (2004) [23], Steiner and Reisinger (2010) [24] and Huang (2011) [25] classify there are four main aspects on Intercultural Competence and Competence of Communication that every tour guide must comply with.

The aspects mentioned are cultural competence (cognitive component/knowledge), language competence (psychomotor features/behaviour), motivasi (component affective) and situational features to support their role as the mediator in creating effective communication in intercultural context in guiding session.

\subsection{Data Collection Procedure}

Questionnaires were distributed at the end of the guiding session to be fulfilled by Japanese tourists. This is to ensure the Japanese tourists participated in the tour guiding session at the maximum level and gain knowledge through the experience of participating in the tour guide. The questionnaires were distributed by the tourist guide. In the final section of the questionnaire, there was a comment section to get an more feedbacks from the tourists to get the opportunity to get insights from their perspective on the tour guide session.

\subsection{Data Analysis}

Data were analyzed using descriptive analysis and inferences statistics. Descriptive analysis were used to present data in "easy to understand form" and gives an overview of the characteristic of the sample taken from the population such as mean, median, standard deviation, 
variance, maximum and minimum scores data. Inferential statistic was used for making sample inferences of the population represented by the sample and carried out using SPSS 20:

- Mean is identified to the usage level of Japanese politeness among Japanese speaker tourist guide.

- Independent sample t-test is performed to determine if there is a significant effect of tour session smoothness on tourists' satisfaction.

- Independent sample t-test is performed to determine if there is a significant effect of the Japanese speaker tourist Japanese politeness's practice on tourists' satisfaction.

\section{FINDING AND DISCUSSION}

Mean is identified as the measurement for the usage level of Japanese politeness among Japanese speaker Malaysian tour guide. The mean for the politeness is 4.52 which approaching the Likert scale of 5 in questionnaire giving out information which can be seen in Table 2 below a total majority of 136 respondents are very satisfied with the usage level of Japanese politeness, followed 74 respondents are satisfied, 16 respondents are less satisfied and only one respondent is not satisfied with the usage level of the politeness among the tour guide.

For objective 2, it is shown in the t-test equality of means in table 4 , the 2 -tailed significant value is 0.000 which is less than 0.05 indicates there is a significant effect on the level of satisfaction of Japanese tourists corresponding to the smoothness of the tour guiding session conducted by the tour guide. Based on the mean of the smoothness of the guiding session in the table 3 , it was found that satisfaction level varies corresponding to the level of smoothness of tour guiding session. The conclusion is Japanese tourists are very satisfied with the smoothness of the guiding session. The satisfaction of the tourists depends on the tour guide. Their knowledge of the site visited, communication and excellent hospitality skills play a significant role, to some extent shaping the guiding session into a meaningful experience. Thus, the efficiency of tour guide performance is the utmost influencing factor in tourism industry [26].

Table 1 Mean of the usage level of Japanese politeness among Japanese speaker Malaysian tour guide.

\begin{tabular}{ccccc}
\hline & & Mean of Politeness & \multicolumn{2}{c}{ Mean of } \\
Verbal Politeness & \multicolumn{2}{c}{ Mean of Non-Verbal } \\
Politeness
\end{tabular}

Table 2 Frequency of Mean of Politeness

\begin{tabular}{cccccc}
\hline & Frequency & Percent & Valid Percent & Cumulative Percent \\
\hline \multirow{4}{*}{ Valid } & Dissatisfied & 1 & .4 & .4 & .4 \\
& Less satisfied & 16 & 7.0 & 7.0 & 7.5 \\
& Satisfied & 74 & 32.6 & 32.6 & 40.1 \\
& Very satisfied & 136 & 59.9 & 59.9 & 100.0 \\
\hline
\end{tabular}

Table 3 Mean for Satisfaction on smoothness of guiding session

\begin{tabular}{llrrrr}
\hline & Level of smoothness & N & Mean & Std. Deviation & \multicolumn{2}{c}{ Std. Error Mean } \\
\hline Mean of & low & 40 & 3.1403 & .44190 & .06987 \\
Satisfaction & high & 187 & 4.0808 & .59432 & .04346 \\
\hline
\end{tabular}


Table 4 Independent sample t-test for Satisfaction

\begin{tabular}{|c|c|c|c|c|c|c|c|c|c|}
\hline & & $\begin{array}{l}\text { Levene } \\
\text { for Equ } \\
\text { Varian }\end{array}$ & $\begin{array}{l}\text { Test } \\
\text { lity of } \\
\text { es }\end{array}$ & & & t-test & For Equality & f Means & \\
\hline & & $\mathrm{F}$ & Sig. & $\mathrm{t}$ & $\mathrm{df}$ & $\begin{array}{l}\text { Sig. (2- } \\
\text { tailed) }\end{array}$ & $\begin{array}{c}\text { Mean } \\
\text { Difference }\end{array}$ & $\begin{array}{l}\text { Std. Error } \\
\text { Difference }\end{array}$ & $\begin{array}{l}95 \% \text { Confidence } \\
\text { Interval of the } \\
\text { Difference }\end{array}$ \\
\hline & & & & & & & & & Lower Upper \\
\hline & $\begin{array}{l}\text { Equal } \\
\text { variances } \\
\text { assumed }\end{array}$ & 6.824 & .010 & -6.011 & 225 & .000 & -.94940 & .15795 & $-1.26065-.63814$ \\
\hline $\begin{array}{l}\text { Mean of } \\
\text { Satisfaction }\end{array}$ & $\begin{array}{l}\text { Equal } \\
\text { variances } \\
\text { not } \\
\text { assumed }\end{array}$ & & & -9.988 & 25.993 & .000 & -.94940 & .09506 & $-1.14479-.75400$ \\
\hline
\end{tabular}

Table 5 Mean for Satisfaction on Japanese politeness of practice

\begin{tabular}{llrrrr}
\hline & Level of Politeness & N & Mean & Std. Deviation & \multicolumn{1}{c}{ Std. Error Mean } \\
\hline Mean of & low & 17 & 3.0368 & .34665 & .08407 \\
Satisfaction & high & 210 & 3.9862 & .64280 & .04436 \\
\hline
\end{tabular}

Table 6 Independent sample t-test for Satisfaction

\begin{tabular}{|c|c|c|c|c|c|c|c|c|c|c|}
\hline & & $\begin{array}{l}\text { Levene' } \\
\text { for Equa } \\
\text { Variar }\end{array}$ & $\begin{array}{l}\text { S Test } \\
\text { lity of } \\
\text { aces }\end{array}$ & & & t-test f & or Equality & of Means & & \\
\hline & & $\mathrm{F}$ & Sig. & $\mathrm{t}$ & df & $\begin{array}{l}\text { Sig. (2- } \\
\text { tailed) }\end{array}$ & $\begin{array}{c}\text { Mean } \\
\text { Difference }\end{array}$ & $\begin{array}{l}\text { Std. Error } \\
\text { Difference }\end{array}$ & $\begin{array}{c}95 \% \text { Conf } \\
\text { Interval } \\
\text { Differe }\end{array}$ & $\begin{array}{l}\text { idence } \\
\text { of the } \\
\text { nce }\end{array}$ \\
\hline & & & & & & & & & Lower & Upper \\
\hline & $\begin{array}{l}\text { Equal } \\
\text { variances } \\
\text { assumed }\end{array}$ & 6.824 & .010 & -6.011 & 225 & .000 & -.94940 & .15795 & -1.26065 & -.63814 \\
\hline Mean of Satisfaction & $\begin{array}{l}\text { Equal } \\
\text { variances } \\
\text { not } \\
\text { assumed }\end{array}$ & & & -9.988 & 25.993 & .000 & -.94940 & .09506 & -1.14479 & -.75400 \\
\hline
\end{tabular}

For objective 3 , it is shown in the t-test equality of means in table 6 , the 2-tailed significant value is 0.000 which is less than 0.05 indicates there is a significant effect on the level of satisfaction of Japanese tourists corresponding to the usage level Japanese politeness practice by tour guide. Based on the mean of the usage level Japanese politeness practice by tour guide in the table 5 , it was found that satisfaction level varies corresponding to the usage level Japanese politeness practice by tour guide. The conclusion is Japanese tourists are very satisfied with usage level Japanese politeness practice by tour guide. This proved the tour guide succeed in understanding the nature of the Japanese language and cultural elements of Japanese society. These two elements are the steppingstone in mastering Japanese politeness language which will contribute to politeness in communication. Politeness is important in a communication especially when interacting with Japanese tourists [27]. 


\section{CONCLUSION}

This research found that majority of the Japanese tourists are very satisfied with the usage level of the tourists guide Japanese politeness as the they successfully adhere to the rule of politeness in Japanese society. Besides that, the level of politeness is the factor in influencing the smoothness of the tour guiding session. Thus, finding of this research is very crucial to the tourists guide, especially to Ministry of Tourism in revising their Japanese curriculum and delve into more strategies to improve the tourists guide Japanese proficiency skill as the Japanese honorific language is considered hard to acquire. On top of that, the smoothness of tour guiding session also influencing the satisfaction of the tourists. Tourists guides must provide the best hospitality to the tourists as it will affect the satisfaction to some extent such as cater to the tourists' welfare, all ear to the tourists' complaint and so forth. This finding is important for Ministry of Tourism to train the tourists guide to the maximum level in order to successfully organizing and conducting the tour trip. Politeness is needed to avoid Face threatening act (FTA) in interaction.

As the recommendation for the next research, it is recommended to conduct an interview with the Japanese tourists as future researcher can get the real thought of the tourists regarding the contributions of the factors influencing their satisfaction of the tour guiding and get an a wider insights of the opinion of the tourists his/herself. It is advised to conduct a research on the necessity of emphasizing of the Japanese politeness in business occasion conducted by non-native speakers.

\section{ACKNOWLEDGMENT}

Thank you to the Malaysia Ministry of Education (MOE) and University Malaysia Terengganu (UMT) for the financial supports through FRGS (Ref.Code: FRGS/1/2018/SSI01/UMT/03/2)

\section{REFERENCES}

[1] D. Yamamoto and A. M. Gill, Emerging trends in Japanese package tourism. Journal of Travel Research, 38(2) (1999) 134-143. DOI: https://doi.org/10.1177/004728759903800206

[2] M. Takajima, Hinihongo bogowasha kankoogaido ni motomerareru Nihongo noryoku to hyooka no sokumen-Tsuaa opereetaa shain no choosa kara. $J F$ Oberlin University NII-Electronic Library Service, (2011) 33-45.

[3] W. Izumi, A. Ito and E. Ishihara, What are the Problem with Business Japanese Competencies? A Study Based on Surveys of Business People Working in Japan-Related Workplace. Proceedings of CLaSIC. 2014.
[4] R. A. Rashid, I. R. Ismail, R. Ismail and R. Mamat, Impoliteness in Japanese Language by Malaysian Tourist Guide. GEMA ONLINE JOURNAL OF LANGUAGE STUDIES, 17(3) (2017) 86-105. DOI: https://doi.org/10.17576/gema-2017-1703-06

[5] X. Liu and T. J. Allen, A study of linguistic politeness in Japanese. Open Journal of Modern Linguistics, 4(05) (2014) 651. DOI: https://doi.org/10.4236/ojml.2014.45056

[6] Y. A. N. Yi-bo, The comparative study on politeness between Chinese and English. US-China Foreign Language, (2015) 544. DOI: https://doi.org/10.17265/1539-8080/2015.07.009

[7] A. Sariyan, Santun berbahasa. Dewan Bahasa dan Pustaka. 2007.

[8] E. Goffman, An Analysis of Ritual Elements in Social Interaction. In Sociology and social research 72(2) (1967) 5-45.

[9] R. Lakoff, Language and Woman's Place. 2(1) (1973) 45-80.

[10] H. P. Grice, Logic and conversation. In Speech acts. (1975) 41-58. Brill. http://www.sfu.ca/ jeffpell/Cogs300/GriceLogicConver s75.pdf

[11] T. Yamazaki, Politeness: How it is realized in a speech act. Ann. Rep. Faculty Of Education, Iwate University, 60(2) (2001) 19-34. DOI: http://ci.nii.ac.jp/naid/110000109258/en/

[12] Y. Matsumoto, Reexamination of the universality of face: Politeness phenomena in Japanese. Journal of pragmatics, 12(4) (1988) 403-426. DOI: https://doi.org/10.1016/0378-2166(88)90003-3

[13] S. Ide, Formal forms and discernment: Two neglected aspects of universals of linguistic politeness. Multilingua-journal of cross-cultural and interlanguage communication, 8(2-3) (1989) 223-248. DOI: https://doi.org/10.1515/mult.1989.8.2-3.223

[14] C. D. Dunn, Formal forms or verbal strategies? Politeness theory and Japanese business etiquette training. Journal of Pragmatics, 43(15) (2011) 36433654.

DOI: https://doi.org/10.1016/j.pragma.2011.06.003

[15] S. Ide, Kokusaika shakai no naka no keii hyoogen ['Keii hyoogen'in an internationalizing society]. Nihongogaku, 20(4) (2001) 4-13.

[16] E. Takamizawa, Group orientation in Japan: Analysis and application to missions. Torch Trinity Journal, 4(4) (2001) 34-45. 
[17] S. Enomoto, The management of politeness in Japanese tour guiding discourse. Japanese Studies, 18(3) (1998) 295-310.

[18] R. Mamat, Ciri-ciri perbualan bahasa Jepun oleh penutur Malaysia berbangsa Cina dalam industri pelancongan negara. Jurnal Linguistik, 11(1) (2010).

[19] R. Mamat, H. A. Halim and N. Abd Rahim, Celahan dalam Perbualan Pemandu Pelancong Malaysia dan Pelancong Jepun. GEMA Online ${ }^{\circledR}$ Journal of Language Studies, 12(3) (2012).

[20] J. Garay, Linguistic Politeness of Tourism Personnel: Social Interaction among Local Tourists in Context. International Journal of Linguistics, Literature and Translation, 2(5) (2019) 55-82.

[21] A. Andriyani, D. Djatmika, S. Sumarlam and E. Rahayu, Learning from Face-Threatening Acts by Tourism Workers in Bali: The Impacts of CrossCultural Misunderstanding. Journal of Social Studies Education Research, 10(3) (2019) 64-81.

[22] X.Yu, B.Weiler, \& S.Ham, Intercultural communication and mediation: A framework for analysing the intercultural competence of Chinese tour guides. Journal of Vacation Marketing, 8(1) (2002) 7587.

[23] D. Leclerc and J. N. Martin, Tour guide communication competence: French, German and American tourists' perceptions. International Journal of Intercultural Relations, 28(3-4) (2004) 181-200. DOI: https://doi.org/10.1016/j.ijintrel.2004.06.006

[24] C. J. Steiner and Y. Reisinger, Enriching the tourist and host intercultural experience by reconceptualising communication. Journal of Tourism and Cultural Change, 2(2) (2004) 118-137. DOI: https://doi.org/10.1080/14766820408668172

[25] Y. Huang, Identity negotiation in relation to context of communication. Theory and practice in language studies, 1(3) (2011) 219-225. DOI: https://doi.org/10.4304/tpls.1.3.219-225

[26] M. Y. Çetinkaya and Z. Öter, Role of tour guides on tourist satisfaction level in guided tours and impact on re-visiting Intention: a research in Istanbul. European Journal of Tourism, Hospitality and Recreation, 7(1) (2016) 40-54. DOI: https://doi.org/10.1515/ejthr-2016-0005

[27] Y. Reisinger and L. Turner, A cultural analysis of Japanese tourists: challenges for tourism marketers. European Journal of Marketing. 1999. DOI: https://doi.org/10.1108/03090569910292348 